\title{
SISTEM PENDETEKSI PERUBAHAN LAHAN HIJAU DI JABODETABEK
}

\author{
Andree Phanderson ${ }^{1}$, Dyah Erny Herwindiati ${ }^{2}$, Bagus Mulyawan ${ }^{3}$ \\ Program Studi Teknik Informatika, Fakultas Teknologi Informasi, Universitas Tarumanagara, \\ Jln. Letjen S. Parman No. 1, Jakarta, 11440, Indonesia \\ E-mail:1'andreep.ti@stu.untar.ac.id, ${ }^{2}$ dyahh@fti.untar.ac.id, ${ }^{3}$ bagus@fti.untar.ac.id
}

\begin{abstract}
Abstrak
Perubahan lahan hijau di Jabodetabek telah menjadi hal yang sangat penting untuk diperhatikan oleh pemerintah Indonesia. Klasifikasi lahan hijau ini menggunakan citra Band 1, 2, 3, 4 dan 5 dari Landsat 8. Sebelum dilakukan klasifikasi, citra yang didapat dari satelit Landsat 8 akan dikoreksi terlebih dahulu menggunakan algoritma koreksi radiometri yaitu algoritma mini-max. Setelah dilakukan proses koreksi radiometri, klasifikasi lahan hijau akan dilakukan dengan metode NDVI (Normalized Difference Vegetation Index) dan SAVI (Soil Adjusted Vegetation Index). Objek atau area tersebut akan diklasifisikan dengan lahan hijau apabila hasil dari nilai NDVI lebih besar atau sama dengan 0.3. Setelah itu hasil klasifikasi dibagi menjadi 2 (dua) kategori, yaitu $Y_{1}$ dan $Y_{2}$ dengan metode dummy dependent variable. Dummy Dependent Variable ini akan digunakan dalam metode regresi linier untuk melakukan klasifikasi area yang telah dipilih di Jabodetabek. Untuk membuktikan apakah hasil dari sistem dapat dipercaya atau tidak, hasil klasifikasi akan dibandingkan dengan gambar asli yang terlihat di Google Earth. Penurunan jumlah lahan hijau terbesar, terdapat pada wilayah Bogor, bulan Mei 2015, yaitu sebesar $325.7368 \mathrm{Km}^{2}$.
\end{abstract}

Kata kunci-Dummy Dependent Variable, Koreksi Radiometri, NDVI, Regresi Linier, SAVI.

\begin{abstract}
Change of green area in Jakarta, Bogor, Depok, Tangerang and Bekasi (Jabodetabek) has been something very important. Classification of green area aims to do classification in Jabodetabek using Landsat 8 satellite images, band 1, 2, 3, 4 and 5. Before classification was done, the satellite images will be corrected using Radiometric Correction method called Mini-max algorithm. After doing radiometric correction, the classification will use the NDVI (Normalized Difference Vegetation Index) and SAVI (Soil Adjusted Vegetation Index) method. The selected area will be classified as green when NDVI values similar or has more than 0.3. After perform two categories, $Y_{1}$ and $Y_{2}$ are selected by NDVI values using dummy dependent variable. Linear regression method use that dummy dependent variable to classify the selected area in Jabodetabek. To see how can we trust the result, the classified area will be compared with the appearance of selected area in Google Earth. The highest degradation of green area is in Bogor, May 2015, 325.7368 $\mathrm{Km}^{2}$.
\end{abstract}

Keywords—Dummy Dependent Variable, NDVI, Linear Regression, Radiometric Correction, SAVI. 


\section{PENDAHULUAN}

Penggunaan lahan hijau di Jabodetabek telah menjadi hal yang sangat penting untuk diperhatikan oleh pemerintah. Seiring berkembangnya jumlah penduduk yang bermukim atau bermigrasi dari kota lain ke Jabodetabek, maka ketersediaan lahan hijau pun semakin berkurang. Dengan berkurangnya ketersediaan lahan hijau, maka banjir akan semakin mudah terjadi karena daya serap air semakin berkurang.

Tujuan penelitian ini adalah untuk mengetahui jumlah perubahan lahan hijau yang terjadi di Jabodetabek dari tahun ke tahun secara periodic yaitu 6 (enam) bulan sekali. Pengklasifikasian lahan hijau ini menggunakan algoritma mini-max untuk melakukan koreksi radiometri terhadap citra, metode NDVI (Normalized Difference Vegetation Index), SAVI (Soil Adjusted Vegetation Index) dan Regresi Linier untuk mengklasifikasikan lahan hijau.

\section{METODE PENELITIAN}

\subsection{Minimum-Maximum Normalization}

Metode ini mengasumsikan gambar subjek harus memiliki piksel minimum dan piksel maksimum yang sama seperti gambar referensinya pada setiap bandnya. Koefisisien normalisasi untuk metode minimum dan maksimum ini adalah [1]:

$$
\begin{gathered}
a_{k}=\frac{y_{k \max }-y_{k \min }}{X_{k \max }-X_{k \min }} \\
b_{k}=y_{k \min }-a_{k} X_{k \min } \\
y k^{\prime}[i, j]=a_{k} X_{k} \text { piksel }+b_{k}
\end{gathered}
$$

Keterangan:

$\mathrm{k}=$ indeks ke pada citra

$\mathrm{a}_{\mathrm{k}}, \mathrm{b}_{\mathrm{k}}=$ Konstanta normalisasi untuk band $\mathrm{ke} \mathrm{k}$

$Y_{\mathrm{kmax}}=$ Nilai maksimum piksel citra referensi

$\mathrm{Y}_{\mathrm{kmin}}=$ Nilai minimum piksel citra referensi

$\mathrm{X}_{\mathrm{kmax}}=$ Nilai maksimum piksel citra yang dikoreksi

$\mathrm{X}_{\mathrm{kmin}}=$ Nilai minimum piksel citra yang dikoreksi

$\mathrm{yk}^{\prime}[\mathrm{i}, \mathrm{j}]=$ Nilai piksel pada baris ke i dan kolom ke j citra yang dikoreksi

\subsection{Normalized Difference Vegetation Index(NDVI)}

Normalized Difference Vegetation Index (NDVI)adalah metode untuk menghitung kuantitas vegetasi dengan membandingkan perbedaan antara near-infrared (refleksi dari vegetasi) dan red light (yang diserap oleh vegetasi). NDVI selalu berada pada jarak antara -1 sampai 1.[2]

Formula untuk menghitung NDVI adalah sebagai berikut:

$$
\mathrm{NDVI}=\frac{(N I R-R e d)}{(N I R+R e d)}
$$

Keterangan:

NDVI = Nilai vegetasi dari suatu area.

$\mathrm{NIR}=$ Citra band 5 pada satelit Landsat 8 .

Red $=$ Citra band 4 pada satelit Landsat 8 . 
Pada persamaan NDVI lebih besar atau sama dengan 0.3 maka nilai objek atau area tersebut diklasifikasikan sebagai objek atau area hijau. Sebaliknya, jika persamaan NDVI lebih kecil dari 0.3 , maka objek atau area tersebut diklasifikasikansebagai objek atau area yang bukan hijau.

\subsection{Soil Adjusted Vegetation Index(SAVI)}

Di daerah dimana tutupan vegetatif rendah, yaitu $<40$ persen dan permukaan tanah terpapar, pantulan cahaya dari spektrum merah dan near-infrared dapat mempengaruhi nilai indeks vegetasi. Permasalahan ini lah yang menjadi hal utama ketika membandingkan nilai vegetasi pada permukaan tanah yang berbeda. Indeks vegetasi ini dikembangkan sebagai modifikasi dari Normalized Difference Vegetation Index untuk mengoreksi kecerahan tanah saat tutupan vegetatifrendah.[3]

Formula untuk menghitung SAVI adalah:

$$
\mathrm{SAVI}=\frac{(\mathrm{NIR}-\mathrm{Red})}{(\mathrm{NIR}+\operatorname{Red}+\mathrm{L})} *(1+\mathrm{L})
$$

Keterangan:

SAVI $=$ Nilai vegetasi dari suatu area.

$\mathrm{NIR}=$ Citra band 5 pada satelit Landsat 8 .

Red $=$ Citra band 4 pada satelit Landsat 8 .

$\mathrm{L}=$ Faktor kalibrasi tanah adalah $0.5[4]$

\subsection{Regresi Linier}

Regresi linier sederhana adalah metode statistik yang berfungsi untuk menguji sejauh mana hubungan sebab akibat antara variabel faktor penyebab terhadap variabel faktor akibatnya. Faktor penyebab pada umumnya dilambangkan dengan $\mathrm{X}$ sedangkan faktor akibat umumnya dilambangkan dengan Y [5].

Formula untuk menghitung regresi linier sederhana satu variabel adalah sebagai berikut:

$$
\begin{aligned}
& Y_{1}=b_{0}+b_{1} X \\
& Y_{2}=b_{0}+b_{1} X
\end{aligned}
$$

Dengan

$$
\begin{gathered}
X=X_{0}, X_{1} \\
B_{a}=\left(X^{T} X\right)^{-1} *\left(X^{T} * Y_{1}\right) \\
B_{b}=\left(X^{T} X\right)^{-1} *\left(X^{T} * Y_{2}\right)
\end{gathered}
$$

Keterangan:

$\mathrm{b}_{0}=$ Nilai titik potong garis regresi

$\mathrm{b}_{1}=$ Nilai koefisien regresi berkaitan dengan faktor penyebab

$\mathrm{X}=$ Matriks yang berisi $\mathrm{X}_{0}$ dan $\mathrm{X}_{1}$

$\mathrm{Y}_{1}, \mathrm{Y}_{2}=$ Vektor nilai dengan dummy dependent variable.

$\mathrm{X}^{\mathrm{T}}=$ Transpose matriks $\mathrm{X}$

$(\mathrm{X})^{-1}=$ Invers dari matriks $\mathrm{X}$

Formula untuk menghitung regresi linier sederhana dua variabel adalah sebagai berikut:

$$
\begin{aligned}
& Y_{1}=b_{0}+b_{1} X_{1}+b_{2} X_{2} \\
& Y_{2}=b_{0}+b_{1} X_{1}+b_{2} X_{2}
\end{aligned}
$$


Dengan

$$
\begin{gathered}
X=X_{0}, X_{1}, X_{2} \\
B_{a}=\left(X^{T} X\right)^{-1} *\left(X^{T} * Y_{1}\right) \\
B_{b}=\left(X^{T} X\right)^{-1} *\left(X^{T} * Y_{2}\right)
\end{gathered}
$$

Keterangan:

$\mathrm{b}_{0}=$ Nilai titik potong garis regresi

$\mathrm{b}_{1}=$ Nilai koefisien regresi berkaitan dengan faktor penyebab pertama.

$\mathrm{b}_{2}=$ Nilai koefisien regresi berkaitan dengan faktor penyebab kedua.

$\mathrm{X}=$ Matriks yang berisi $\mathrm{X}_{0}$ dan $\mathrm{X}_{1}$ dan $\mathrm{X}_{2}$.

$\mathrm{Y}_{1}, \mathrm{Y}_{2}=$ Vektor nilai dengan dummy dependent variable.

$\mathrm{X}^{\mathrm{T}}=$ Transpose matriks $\mathrm{X}$.

$(\mathrm{X})^{-1}=$ Invers dari matriks $\mathrm{X}$.

\section{HASIL DAN PEMBAHASAN}

Hasil percobaan klasifikasi lahan hijau yang dilakukan dengan metode regresi linier pada beberapa sampel di kota Jakarta, Bogor, Depok, Tangerang atau Bekasi dapat dilihat pada gambar dibawah:

Tabel 1 Model Regresi Satu Variabel

\begin{tabular}{|c|c|c|}
\hline & B0 & B1 \\
\hline Y1 & -0.415872 & 3.0618505 \\
\hline Y2 & 1.415872 & -3.0618505 \\
\hline
\end{tabular}

Tabel 2 Model Regresi Dua Variabel

\begin{tabular}{|c|c|c|c|}
\hline & B0 & B1 & B2 \\
\hline Y1 & -0.328472 & -712.793704 & 479.396811 \\
\hline Y2 & 1.3284727 & 712.793700 & -479.396808 \\
\hline
\end{tabular}

Model regresi tersebut digunakan untuk mengklasifikasikan lahan hijau karena telah diuji dan mendapatkan keakuratan diatas $90 \%$. Untuk model regresi satu variabel, rata-rata keakuratan yang dihasilkan mencapai $96 \%$ dan untuk model regresi dua variabel, rata-rata keakuratan yang dihasilkan mencapai $90 \%$.

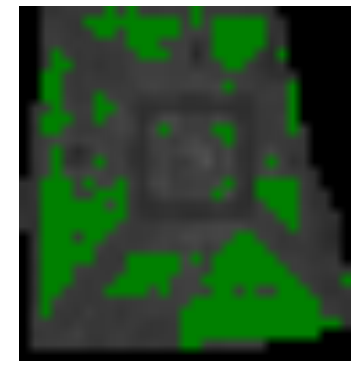

(a)

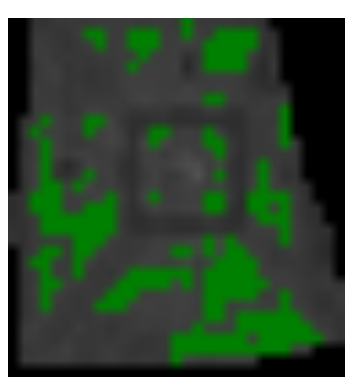

(b)

Gambar 1(a) Deteksi Lahan Hijau pada Monas dengan Model Regresi Satu Variabel (b)Deteksi Lahan Hijau pada Monas dengan Model Regresi Dua Variabel 


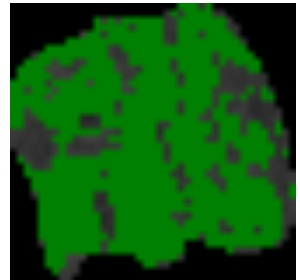

(a)

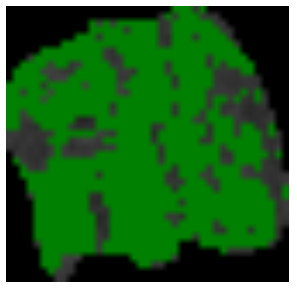

(b)

Gambar 2(a) Deteksi Lahan Hijau pada Kebun Raya Bogor dengan Model Regresi Satu Variabel (b) Deteksi Lahan Hijau pada Kebun Raya Bogor dengan Model Regresi Dua Variabel

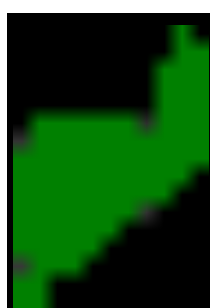

(a)

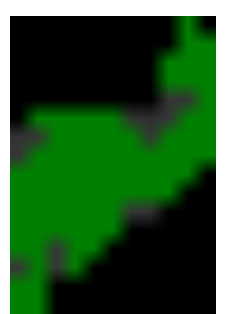

(b)

Gambar 3(a) Deteksi Lahan Hijau pada Situ Rawabadak dengan Model Regresi Satu Variabel (b) Deteksi Lahan Hijau pada Situ Rawabadak dengan Model Regresi Dua Variabel

Keterangan untuk Gambar 1 sampai Gambar 3:

Warna Hijau: Lahan hijau

Selain warna hijau: Bukan lahan hijau

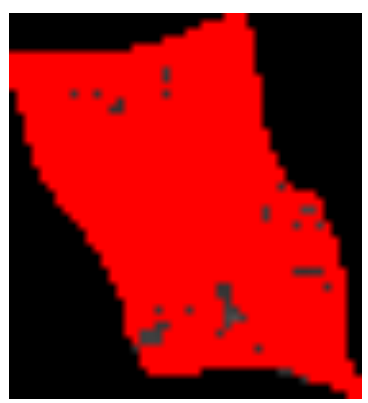

(a)

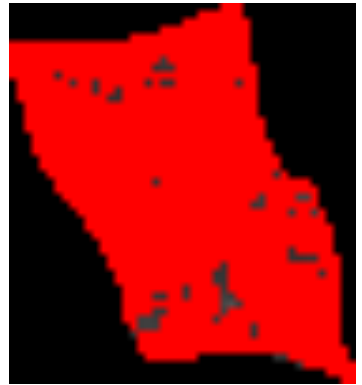

(b)

Gambar 4(a) Deteksi Lahan Tidak Serap Air pada Jembatan Merah dengan Model Regresi Satu Variabel (b) Deteksi Lahan Tidak Serap Air pada Jembatan Merah dengan Model Regresi Dua Variabel

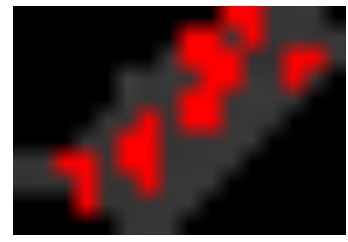

(a)

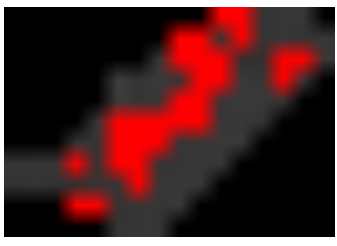

(b)

Gambar 5(a) Deteksi Lahan Tidak Serap Air pada Margonda dengan Model Regresi Satu Variabel (b) Deteksi Lahan Tidak Serap Air pada Margonda dengan Model Regresi Dua Variabel 


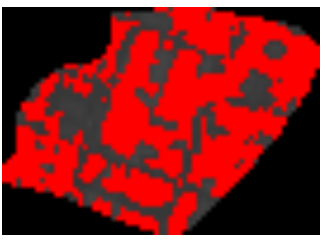

(a)

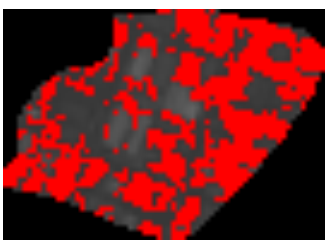

(b)

Gambar 6(a) Deteksi Lahan Tidak Serap Air pada Sukaresmi dengan Model Regresi Satu Variabel

(b) Deteksi Lahan Tidak Serap Air pada Sukaresmi dengan Model Regresi Dua Variabel

Keterangan untuk Gambar 4 sampai Gambar 6:

Warna merah: Lahan tidak Serap Air

Selain warna merah: Lahan serap air

Tabel 3 Hasil Evaluasi Deteksi Lahan Hijau dan Lahan Tidak Serap Air

\begin{tabular}{|c|c|c|c|}
\hline \multirow{2}{*}{ Jenis Lahan } & \multirow{2}{*}{ Sampel } & \multicolumn{2}{|c|}{ Regresi } \\
\cline { 3 - 4 } & Monas & Satu Variabel & Dua Variabel \\
\hline Hijau & Kebun Raya Bogor & $97.9483 \%$ & $94.7189 \%$ \\
\hline Hijau & Situ Rawabadak & $100 \%$ & $89.0422 \%$ \\
\hline Hijau & Jembatan Merah & $83.1369 \%$ & $98.8888 \%$ \\
\hline Tidak Serap Air & Margo City & $68.5393 \%$ & $64.0449 \%$ \\
\hline Tidak Serap Air & Sukaresmi, Cikarang Selatan & $72.1017 \%$ & $61.4043 \%$ \\
\hline Tidak Serap Air &
\end{tabular}

Selain itu, percobaan juga dilakukan pada wilayah Jakarta dan Bogor. Hasil percobaan untuk semester ganjil tahun 2014dapat dilihat pada gambar di bawah:

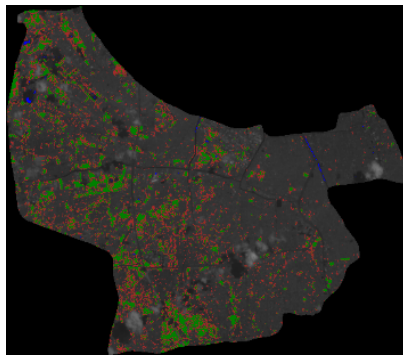

(a)

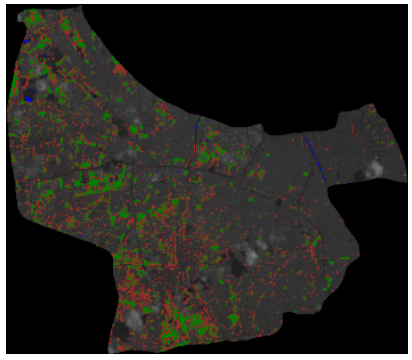

(b)

Gambar 7(a)Deteksi Lahan Jakarta Barat Tahun 2014 dengan Model Regresi Satu Variabel (b) Deteksi Lahan Jakarta Barat Tahun 2014 dengan Model Regresi Dua Variabel

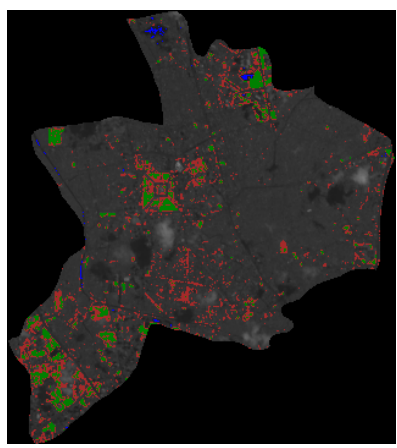

(a)

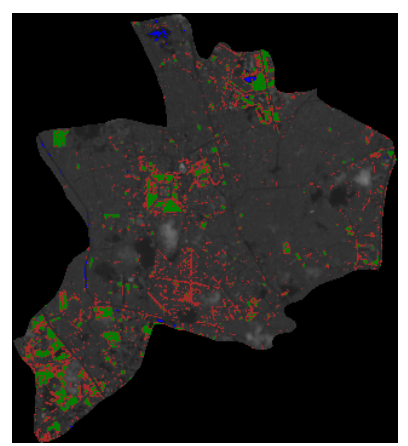

(b)

Gambar 8 (a) Deteksi Lahan Jakarta Pusat Tahun 2014 dengan Model Regresi Satu Variabel (b) Deteksi Lahan Jakarta Pusat Tahun 2014 dengan Model Regresi Dua Variabel 


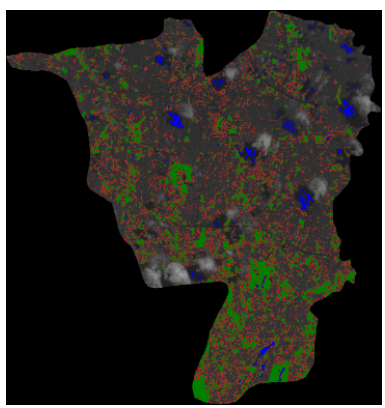

(a)

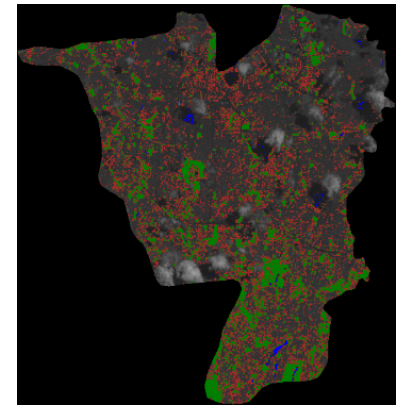

(b)

Gambar 9Deteksi Lahan Jakarta Selatan Tahun 2014 dengan Model Regresi Satu Variabel (b) Deteksi Lahan Jakarta Selatan Tahun 2014 dengan Model Regresi Dua Variabel

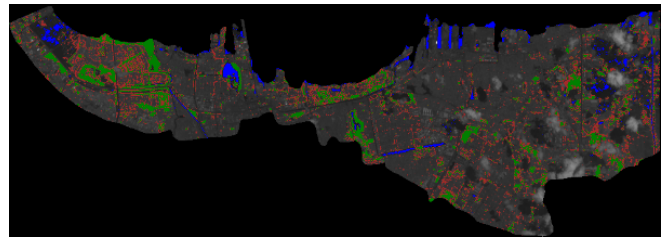

Gambar 10Deteksi Lahan Jakarta Utara Tahun 2014 dengan Model Regresi Satu Variabel

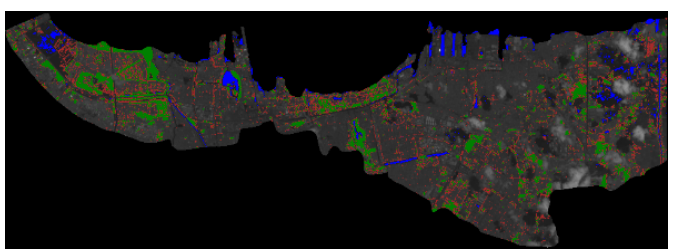

Gambar 11Deteksi Lahan Jakarta Utara Tahun 2014 dengan Model Regresi Dua Variabel

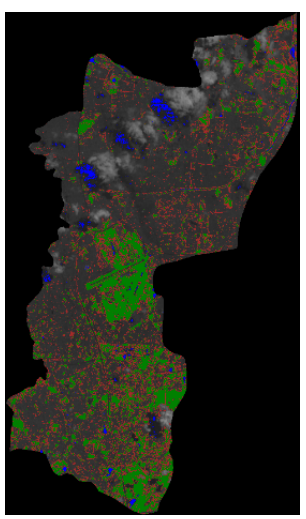

(a)

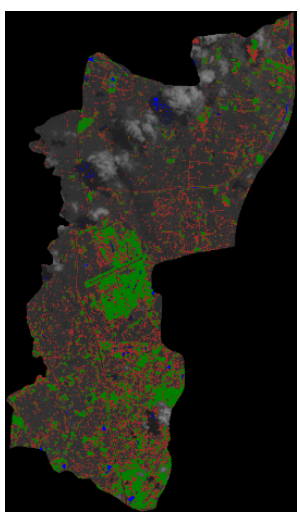

(b)

Gambar 12(a)Deteksi Lahan Jakarta Timur Tahun 2014 dengan Model Regresi Satu Variabel (b) Deteksi Lahan Jakarta Timur Tahun 2014 dengan Model Regresi Dua Variabel

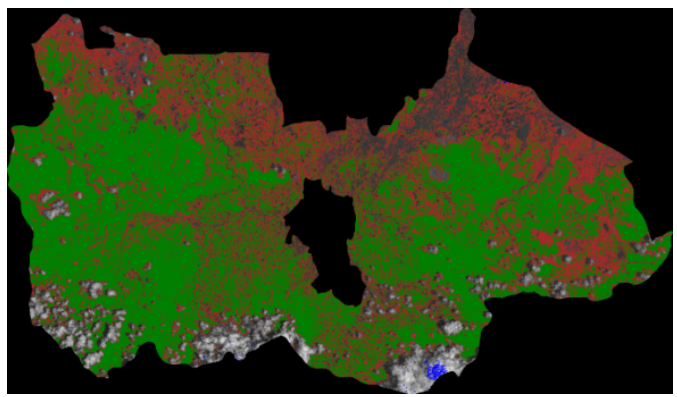

Gambar 13Deteksi Lahan Kabupaten Bogor Tahun 2014 dengan Model Regresi Satu Variabel 


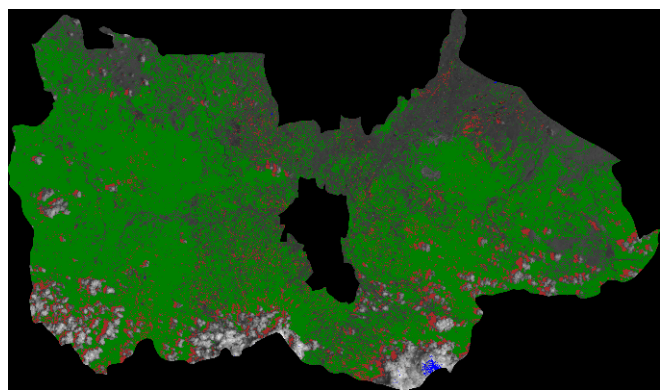

Gambar 14 Deteksi Lahan Kabupaten Bogor Tahun 2014 dengan Model Regresi Dua Variabel

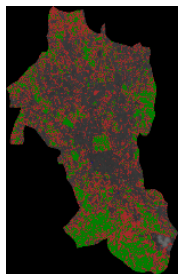

(a)

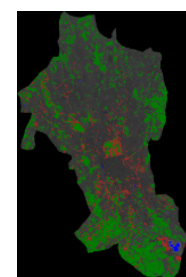

(b)

Gambar 15 (a) Deteksi Lahan Kota Bogor Tahun 2014 dengan Model Regresi Satu Variabel (b) Deteksi Lahan Kota Bogor Tahun 2014 dengan Model Regresi Dua Variabel

Keterangan untuk Gambar 7 sampai Gambar 15:

Warna Biru: Lahan air

Warna Coklat: Lahan kosong

Warna Hijau: Lahan hijau

Selain warna biru, warna coklat dan warna hijau: Lahan tidak serap air

Setelah berhasil melakukan percobaan pada setiap wilayah di Jakarta dan Bogor, maka selanjutnya dilakukan evaluasi lahan hijau di Jabodetabek secara periodik. Hasil evaluasi lahan hijau secara periodik untuk tahun 2014 hingga 2016 dapat dilihat pada Tabel 4 dan Tabel 5.

Tabel 4 Hasil Evaluasi Deteksi Lahan Hijau di Jabodetabek dengan Model RegresiSatu Variabel

\begin{tabular}{|c|c|c|c|c|}
\hline Tahun & Kota & $\begin{array}{c}\text { Luas Lahan Hijau } \\
\text { (NDVI) }\end{array}$ & $\begin{array}{c}\text { Luas Lahan Hijau } \\
\text { (Regresi) }\end{array}$ & $\begin{array}{c}\text { Ketepatan } \\
(\%)\end{array}$ \\
\hline 22 April 2014 & Jakarta & $58.2552 \mathrm{Km}^{2}$ & $58.2714 \mathrm{Km}^{2}$ & $99.9975 \%$ \\
\hline 31 Oktober 2014 & Jakarta & $15.5502 \mathrm{Km}^{2}$ & $15.6186 \mathrm{Km}^{2}$ & $99.9896 \%$ \\
\hline 27 Mei 2015 & Jakarta & $23.9724 \mathrm{Km}^{2}$ & $23.9733 \mathrm{Km}^{2}$ & $99.9998 \%$ \\
\hline 31 Agustus 2015 & Jakarta & $38.3499 \mathrm{Km}^{2}$ & $41.8941 \mathrm{Km}^{2}$ & $99.9998 \%$ \\
\hline 13 Mei 2016 & Jakarta & $57.6999 \mathrm{Km}^{2}$ & $57.7044 \mathrm{Km}^{2}$ & $99.9993 \%$ \\
\hline 17 Agustus 2016 & Jakarta & $53.0099 \mathrm{Km}^{2}$ & $63.0225 \mathrm{Km}^{2}$ & $99.9980 \%$ \\
\hline 22 April 2014 & Bogor & $2121.6402 \mathrm{Km}^{2}$ & $2122.0263 \mathrm{Km}^{2}$ & $99.9874 \%$ \\
\hline 31 Oktober 2014 & Bogor & $1495.5390 \mathrm{Km}^{2}$ & $1496.8575 \mathrm{Km}^{2}$ & $99.9571 \%$ \\
\hline 27 Mei 2015 & Bogor & $1168.1523 \mathrm{Km}^{2}$ & $1169.7822 \mathrm{Km}^{2}$ & $99.9470 \%$ \\
\hline 31 Agustus 2015 & Bogor & $1773.1476 \mathrm{Km}^{2}$ & $1773.279 \mathrm{Km}^{2}$ & $99.9957 \%$ \\
\hline 13 Mei 2016 & Bogor & $2088.3996 \mathrm{Km}^{2}$ & $2088.6291 \mathrm{Km}^{2}$ & $99.9925 \%$ \\
\hline 17 Agustus 2016 & Bogor & $2140.7742 \mathrm{Km}^{2}$ & $2141.0973 \mathrm{Km}^{2}$ & $99.9895 \%$ \\
\hline 22 April 2014 & Depok & $69.4134 \mathrm{Km}^{2}$ & $69.4143 \mathrm{Km}^{2}$ & $99.9995 \%$ \\
\hline 31 Oktober 2014 & Depok & $11.0457 \mathrm{Km}^{2}$ & $11.0493 \mathrm{Km}^{2}$ & $99.9981 \%$ \\
\hline 27 Mei 2015 & Depok & $31.1472 \mathrm{Km}^{2}$ & $31.1544 \mathrm{Km}^{2}$ & $99.9963 \%$ \\
\hline 31 Agustus 2015 & Depok & $38.5245 \mathrm{Km}^{2}$ & $38.5263 \mathrm{Km}^{2}$ & $99.9990 \%$ \\
\hline 13 Mei 2016 & Depok & $54.7893 \mathrm{Km}^{2}$ & $54.7893 \mathrm{Km}^{2}$ & $100 \%$ \\
\hline 17 Agustus 2016 & Depok & $61.9362 \mathrm{Km}^{2}$ & $61.9398 \mathrm{Km}^{2}$ & $99.9981 \%$ \\
\hline 22 April 2014 & Tangerang & $377.4744 \mathrm{Km}^{2}$ & $377.676 \mathrm{Km}^{2}$ & $99.9851 \%$ \\
\hline 31 Oktober 2014 & Tangerang & $137.9448 \mathrm{Km}^{2}$ & $137.9448 \mathrm{Km}^{2}$ & $100 \%$ \\
\hline 27 Mei 2015 & Tangerang & $186.8751 \mathrm{Km}^{2}$ & $186.9606 \mathrm{Km}^{2}$ & $99.9930 \%$ \\
\hline 31 Agustus 2015 & Tangerang & $112.0338 \mathrm{Km}^{2}$ & $112.095 \mathrm{Km}^{2}$ & $99.9954 \%$ \\
\hline
\end{tabular}


Andree Phanderson, et al., Sistem Pendeteksi Perubahan Lahan Hijau di Jabodetabek

\begin{tabular}{|c|c|c|c|c|}
\hline 13 Mei 2016 & Tangerang & $249.8463 \mathrm{Km}^{2}$ & $249.9408 \mathrm{Km}^{2}$ & $99.9930 \%$ \\
\hline 17 Agustus 2016 & Tangerang & $512.2323 \mathrm{Km}^{2}$ & $512.2773 \mathrm{Km}^{2}$ & $99.9966 \%$ \\
\hline 22 April 2014 & Bekasi & $326.0673 \mathrm{Km}^{2}$ & $326.0862 \mathrm{Km}^{2}$ & $99.9987 \%$ \\
\hline 31 Oktober 2014 & Bekasi & $101.4489 \mathrm{Km}^{2}$ & $101.5902 \mathrm{Km}^{2}$ & $99.9905 \%$ \\
\hline 27 Mei 2015 & Bekasi & $309.2859 \mathrm{Km}^{2}$ & $309.4776 \mathrm{Km}^{2}$ & $99.9871 \%$ \\
\hline 31 Agustus 2015 & Bekasi & $126.7236 \mathrm{Km}^{2}$ & $126.7983 \mathrm{Km}^{2}$ & $99.9950 \%$ \\
\hline 13 Mei 2016 & Bekasi & $610.0254 \mathrm{Km}^{2}$ & $610.0848 \mathrm{Km}^{2}$ & $99.9960 \%$ \\
\hline 17 Agustus 2016 & Bekasi & $299.4381 \mathrm{Km}^{2}$ & $299.6181 \mathrm{Km}^{2}$ & $99.9879 \%$ \\
\hline
\end{tabular}

Tabel 5 Hasil evaluasi deteksi lahan hijau di Jabodetabek dengan model regresi dua variabel

\begin{tabular}{|c|c|c|c|c|}
\hline Tahun & Kota & $\begin{array}{c}\text { Luas Lahan Hijau } \\
\text { (NDVI) }\end{array}$ & $\begin{array}{c}\text { Luas Lahan Hijau } \\
\text { (Regresi) }\end{array}$ & $\begin{array}{c}\text { Ketepatan } \\
(\%)\end{array}$ \\
\hline 22 April 2014 & Jakarta & $58.2552 \mathrm{Km}^{2}$ & $46.0764 \mathrm{Km}^{2}$ & $97.6640 \%$ \\
\hline 31 Oktober 2014 & Jakarta & $15.5502 \mathrm{Km}^{2}$ & $20.6694 \mathrm{Km}^{2}$ & $99.1744 \%$ \\
\hline 27 Mei 2015 & Jakarta & $23.9724 \mathrm{Km}^{2}$ & $13.5045 \mathrm{Km}^{2}$ & $98.3587 \%$ \\
\hline 31 Agustus 2015 & Jakarta & $38.3499 \mathrm{Km}^{2}$ & $15.39 \mathrm{Km}^{2}$ & $96.5162 \%$ \\
\hline 13 Mei 2016 & Jakarta & $57.6999 \mathrm{Km}^{2}$ & $40.2444 \mathrm{Km}^{2}$ & $97.2359 \%$ \\
\hline 17 Agustus 2016 & Jakarta & $53.0099 \mathrm{Km}^{2}$ & $45.7695 \mathrm{Km}^{2}$ & $97.0948 \%$ \\
\hline 22 April 2014 & Bogor & $2121.6402 \mathrm{Km}^{2}$ & $1846.287 \mathrm{Km}^{2}$ & $88.6621 \%$ \\
\hline 31 Oktober 2014 & Bogor & $1495.5390 \mathrm{Km}^{2}$ & $1564.2 \mathrm{Km}^{2}$ & $93.9242 \%$ \\
\hline 27 Mei 2015 & Bogor & $1168.1523 \mathrm{Km}^{2}$ & $1021.9464 \mathrm{Km}^{2}$ & $86.7516 \%$ \\
\hline 31 Agustus 2015 & Bogor & $1773.1476 \mathrm{Km}^{2}$ & $1434.4614 \mathrm{Km}^{2}$ & $88.0942 \%$ \\
\hline 13 Mei 2016 & Bogor & $2088.3996 \mathrm{Km}^{2}$ & $1677.9114 \mathrm{Km}^{2}$ & $85.3548 \%$ \\
\hline 17 Agustus 2016 & Bogor & $2140.7742 \mathrm{Km}^{2}$ & $1756.8315 \mathrm{Km}^{2}$ & $86.2485 \%$ \\
\hline 22 April 2014 & Depok & $69.4134 \mathrm{Km}^{2}$ & $54.5679 \mathrm{Km}^{2}$ & $92.1821 \%$ \\
\hline 31 Oktober 2014 & Depok & $11.0457 \mathrm{Km}^{2}$ & $11.9637 \mathrm{Km}^{2}$ & $98.9567 \%$ \\
\hline 27 Mei 2015 & Depok & $31.1472 \mathrm{Km}^{2}$ & $24.912 \mathrm{Km}^{2}$ & $95.4060 \%$ \\
\hline 31 Agustus 2015 & Depok & $38.5245 \mathrm{Km}^{2}$ & $28.5156 \mathrm{Km}^{2}$ & $94.4658 \%$ \\
\hline 13 Mei 2016 & Depok & $54.7893 \mathrm{Km}^{2}$ & $35.6355 \mathrm{Km}^{2}$ & $90.1932 \%$ \\
\hline 17 Agustus 2016 & Depok & $61.9362 \mathrm{Km}^{2}$ & $44.9226 \mathrm{Km}^{2}$ & $91.1017 \%$ \\
\hline 22 April 2014 & Tangerang & $377.4744 \mathrm{Km}^{2}$ & $354.897 \mathrm{Km}^{2}$ & $95.5959 \%$ \\
\hline 31 Oktober 2014 & Tangerang & $137.9448 \mathrm{Km}^{2}$ & $129.6720 \mathrm{Km}^{2}$ & $96.4965 \%$ \\
\hline 27 Mei 2015 & Tangerang & $186.8751 \mathrm{Km}^{2}$ & $177.3171 \mathrm{Km}^{2}$ & $96.9183 \%$ \\
\hline 31 Agustus 2015 & Tangerang & $112.0338 \mathrm{Km}^{2}$ & $105.075 \mathrm{Km}^{2}$ & $97.9383 \%$ \\
\hline 13 Mei 2016 & Tangerang & $249.8463 \mathrm{Km}^{2}$ & $217.1088 \mathrm{Km}^{2}$ & $96.1159 \%$ \\
\hline 17 Agustus 2016 & Tangerang & $512.2323 \mathrm{Km}^{2}$ & $417.0627 \mathrm{Km}^{2}$ & $92.2250 \%$ \\
\hline 22 April 2014 & Bekasi & $326.0673 \mathrm{Km}^{2}$ & $254.1087 \mathrm{Km}^{2}$ & $94.2107 \%$ \\
\hline 31 Oktober 2014 & Bekasi & $101.4489 \mathrm{Km}^{2}$ & $116.9775 \mathrm{Km}^{2}$ & $97.7353 \%$ \\
\hline 27 Mei 2015 & Bekasi & $309.2859 \mathrm{Km}^{2}$ & $280.9098 \mathrm{Km}^{2}$ & $95.5107 \%$ \\
\hline 31 Agustus 2015 & Bekasi & $126.7236 \mathrm{Km}^{2}$ & $109.899 \mathrm{Km}^{2}$ & $97.7678 \%$ \\
\hline 13 Mei 2016 & Bekasi & $610.0254 \mathrm{Km}^{2}$ & $530.5815 \mathrm{Km}^{2}$ & $93.6812 \%$ \\
\hline 17 Agustus 2016 & Bekasi & $299.4381 \mathrm{Km}^{2}$ & $266.8455 \mathrm{Km}^{2}$ & $96.6015 \%$ \\
\hline
\end{tabular}

Analisis berdasarkan hasil evaluasi deteksi lahan hijau diatas yaitu:

1. Hasil deteksi lahan dilakukan dengan menggunakan data citra Landsat 8. Deteksi lahan hijau dapat dikatakan berhasil karena rata-rata hasil keakuratan pengujian mencapai 90 persen.

2. Jumlah lahan hijau pada wilayah Jakarta, Bogor, Depok, Tangerang dan Bekasi berkurang secara signifikan pada semester genap tahun 2014 dan semester ganjil tahun 2015, dikarenakan terjadi kemarau panjang selama dua periode tersebut. [6]

3. Rata-rata pada proses deteksi menggunakan model regresi satu variabel mendapatkan hasil yang lebih tepat. Hal ini dikarenakan banyaknya variabel yang digunakan dapat mengurangi keakuratan dari suatu model regresi. [7]

4. Hasil yang didapat dari model regresi dua variabel kurang akurat jika dibandingkan dengan hasil yang didapat dari regresi satu variabel. Hal ini disebabkan karena adanya faktor kalibrasi tanah yang digunakan pada rumus Soil Adjusted Vegetation Index (SAVI) serta rumus yang memiliki kemiripan dengan rumus Normalized Difference Vegetation Index (NDVI) yaitu sama-sama menggunakan Band 5 dan Band 4 pada citra Landsat 8 untuk mendapatkan jenis klasifikasi lahan. 


\section{KESIMPULAN}

Berdasarkan percobaan dan pengujian yang telah dilakukan dengan metode regresi linier, maka dapat disimpulkan bahwa:

1. Metode regresi linier dapat digunakan untuk mengklasifikasikan jenis lahan dari citra satelit Landsat 8.

2. Pada wilayah Jakarta tahun 2014, luas lahan hijau di Jakarta mencapai $58 \mathrm{Km}^{2}$, tahun 2015 mencapai $41 \mathrm{Km}^{2}$ dan tahun 2016 mencapai $57 \mathrm{Km}^{2}$.

3. Pada wilayah Bogor tahun 2014, luas lahan hijau di Bogor mencapai $2121 \mathrm{Km}^{2}$, tahun 2015 mencapai $1773 \mathrm{Km}^{2}$ dan tahun 2016 mencapai $2141 \mathrm{Km}^{2}$.

4. Pada wilayah Depok tahun 2014, luas lahan hijau di Depok mencapai $69 \mathrm{Km}^{2}$, tahun 2015 mencapai $38 \mathrm{Km}^{2}$ dan tahun 2016 mencapai $61 \mathrm{Km}^{2}$.

5. Pada wilayah Tangerang tahun 2015 , luas lahan hijau di Tangerang mencapai $377 \mathrm{Km}^{2}$, tahun 2015 mencapai $186 \mathrm{Km}^{2}$ dan tahun 2016 mencapai $512 \mathrm{Km}^{2}$.

6. Pada wilayah Bekasi tahun 2014, luas lahan hijau di Bekasi mencapai $326 \mathrm{Km}^{2}$, tahun 2015 mencapai $309 \mathrm{Km}^{2}$ dan tahun 2016 mencapai $610 \mathrm{Km}^{2}$.

7. Hasil evaluasi pada wilayah Jakarta tahun 2014 hingga 2016 menunjukkan bahwa wilayah Jakarta memiliki sangat sedikit lahan hijau jika dibandingkan dengan wilayah lainnya yaitu Bogor, Depok, Tangerang dan Bekasi. Luas lahan hijau pada wilayah Jakarta tahun 2014 hingga 2016 hanya mencapai $58 \mathrm{Km}^{2}$, sedangkan Bogor mencapai $2141 \mathrm{Km}^{2}$, Depok mencapai $69 \mathrm{Km}^{2}$, Tangerang mencapai $512 \mathrm{Km}^{2}$, dan Bekasi mencapai $610 \mathrm{Km}^{2}$.

8. Hasil yang didapat dari model regresi dua variabel kurang akurat jika dibandingkan dengan hasil yang didapat dari regresi satu variabel. Hal ini disebabkan karena adanya faktor kalibrasi tanah yang digunakan pada rumus Soil Adjusted Vegetation Index (SAVI) serta rumus yang memiliki kemiripan dengan rumus Normalized Difference Vegetation Index (NDVI) yaitu sama-sama menggunakan Band 5 dan Band 4 pada citra Landsat 8 untuk mendapatkan jenis klasifikasi lahan.

\section{DAFTAR PUSTAKA}

[1] Gore, Semma Biday. 2010. Radiometric Correction of Multitemporal Satellite Imagery, Journal of Computer Science, Vol. 9. h.1028, 22 Desember 2017.

[2] GisGeoraphy. 2017, What is NDVI (Normalized Difference Vegetation Index, http://gisgeography.com/ndvi-normalized-difference-vegetation-index/, 22 Desember 2017.

[3] Gtucker, 2011. Soil Adjusted Vegetation Index. http://wiki.landscapetoolbox.org/doku.php/remote_sensing_methods:soiladjusted_vegetation_index, 22 Desember 2017.

[4] Jensen, J.R. 2000, Remote Sensing of The Environmental Earth Resource Perspective, Prentice Hall, 22 Desember 2017.

[5] Dickson Kho. 2015. Analisis Regresi Linear Sederhana (Simpel Linear Regression). http://teknikelektronika.com/analisis-regresi-linear-sederhana-simple-linear-regression/, 22 Desember 2017.

[6] J, Pujiono S. 2015. Kemarau 2015 Jadi Musim Terpanas dalam 40 Abad, https://www.google.com/amp/s/beritagar.id/artiket-amp/sains-tekno/kemarau-2015-jadi-m usim-terpanas-dalam-40-abad/, 22 Desember 2017.

[7] Thorac, J. Dis. 2014. Too Much Covariates in Multivariable Model May Cause the Problem of Overfitting, https://www.ncbi.nlm.nih.gov/pmc/articles/PMC4178069/, 22 Desember 2017. 